\title{
Highly Active Bifunctional Catalyst for SCR of NO with Methane
}

\author{
Jin Won Kim. Hyun-Seok You, ${ }^{\dagger}$ Hyun-Chan Lee, ${ }^{\dagger}$ Jung-Seong Lee, ${ }^{\dagger}$ and Chul Wee Lee ${ }^{\star}$ \\ Advanced Chemical Technology Division, KRICT, Daejeon 305-600, Korea. "E-mail: chtlwee@krictre.kr \\ "Center for Gas Utilization, R\&D Center, Korea Gas Co., Kyunggi-Do, Ansan 425-790, Korea \\ Received March 3, 2006
}

Key Words : De-NOx, Methane, Catalyst, ZSM-5, Layered oxide

\begin{abstract}
Selective catalytic reduction (SCR) of NO with hydrocarbon has received much attention because of its potential application in the removal of NO from exhaust gases. Natural gas is a favourable alternative to automotive fuel due to its easy availability, low price and high hydrogen to carbon ratio. Natural gas fuelled vehicles (NGVs) appear to be attractive to solve the transportation problems and also to reduce the pollution since compared to diesel, the NGV engines produce less emission of $\mathrm{NO}_{x}$ and particulates. $\mathrm{A}$ SCR system which can use methane as a reductant would be beneficial for not only natural gas fuelled facilites, but also stationary $\mathrm{NO}_{\mathrm{x}}$ emission sources where natural gas supply is available. Several metal ion-exchanged zeolites, such as Co- ${ }^{1,2} \mathrm{Mn}-{ }^{3} \mathrm{Ga}_{-}{ }^{4} \mathrm{In}-{ }^{5.6} \mathrm{Pd}-{ }^{7.8}$ and $\mathrm{Ce}-\mathrm{Ag}-\mathrm{ZSM}-5^{9}$ have shown to be active for the SCR of NO with methane. However, water vapor and $\mathrm{SO}_{2}$ present in combustion exhausts may cause severe deactivation of catalyst during the $S C R$ reaction ${ }^{10,11}$
\end{abstract}

In this report, preliminary results on the SCR of NO with methane over catalyst prepared by simple physical mixing of modified layered oxide and Pd/H-ZSM-5 are dealt with. $\mathrm{NO}_{\mathrm{x}}$ conversion of $>85 \%$ was observed in the range of 450 $520^{\circ} \mathrm{C}$ in the presence of $3 \% \mathrm{O}_{2}, 3 \% \mathrm{H}_{2} \mathrm{O}$, and $30 \mathrm{ppm} \mathrm{SO}_{2}$ with GHSV $20,000 \mathrm{~h}^{-1}$.

The $\mathrm{Pd} / \mathrm{H}-\mathrm{ZSM}-5$ catalyst was prepared using $\mathrm{NH}_{4}$-ZSM5 (Zeobuilder, $\mathrm{Si} / \mathrm{Al}=20$ ) by a conventional ion-exchange method using an aqueous $\mathrm{PdCl}_{2}$ and $\mathrm{NH}_{4} \mathrm{OH}$ solution at 80 ${ }^{\circ} \mathrm{C}$, followed by calcination at $500^{\circ} \mathrm{C}$ in He for $4 \mathrm{~h}$. After filtration, the sample was washed with distilled water and dried at $110^{\circ} \mathrm{C}$. For the synthesis of modified layered oxide catalyst, a commercial $\mathrm{MgAl}_{2} \mathrm{O}_{4}$ (SASOL MG50) was used as a support. $\mathrm{MgO} / \mathrm{MgAl}_{2} \mathrm{O}_{4}$ and $\mathrm{CeO}_{2}-\mathrm{MgO} / \mathrm{MgAl}_{2} \mathrm{O}_{4}$ were prepared by impregnating with $\mathrm{Mg}\left(\mathrm{NO}_{3}\right)_{2} \cdot 6 \mathrm{H}_{2} \mathrm{O}$ and $\mathrm{Ce}\left(\mathrm{NO}_{3}\right)_{3} \cdot 6 \mathrm{H}_{2} \mathrm{O}$ solution. The contents of $\mathrm{CeO}_{2}$ and $\mathrm{MgO}$ were 12.3 and $5 \mathrm{wt} \%$, respectively. After oven diying at 110 ${ }^{\circ} \mathrm{C}$, the dried powder was calcined in air at $500^{\circ} \mathrm{C}$ for $5 \mathrm{~h}$. The catalytic study of $N O_{x}$ reduction was performed in a fixed-bed flow reactor at atmospheric pressure. The reaction gas contains a mixture of $1250 \mathrm{ppm} \mathrm{NO}, 4500 \mathrm{ppm} \mathrm{CH}_{4}$, 3$10 \% \mathrm{O}_{2}, 30 \mathrm{ppm} \mathrm{SO}_{2}$ and $3 \% \mathrm{H}_{2} \mathrm{O}$ in $\mathrm{He}$ flow and was fed over a catalyst (ca. $0.18 \mathrm{~g}$ ) at a total flow-rate of $100 \mathrm{~cm}^{3} /$ min, corresponding to a GHSV $=20,000 \mathrm{~h}^{-1}$. The exit gases were analysed by a GC (HP 5890 series II) and a $\mathrm{NO} / \mathrm{NO}_{\mathrm{x}}$ analyser (Kimoto Model 272). The $\mathrm{NO}_{x}$ conversion is determined by the difference between the $\mathrm{NO}_{x}$ concentration before and after reaction. ESR spectra was recorded at $77 \mathrm{~K}$ with a Bnuker ESP 300.

Figure 1 shows the influence of reaction temperature on the activity of Pd/H-ZSM-5 catalyst for the reduction of NO with methane. Over $\mathrm{Pd} / \mathrm{H}-\mathrm{ZSM}-5$, two maximum peaks are observed at temperatures, 425 and $500{ }^{\circ} \mathrm{C}$, indicating the existence of at least two different active sites on the catalyst surface. In our previous work, ${ }^{12}$ both highly dispersed PdO and $\mathrm{Pd}^{21}$ or the protonic sites were shown to be catalytically active for the abatement of $\mathrm{NO}$ by methane and a synergistic activity was anticipated when they were combined properly.

The rise in $\mathrm{NO}_{\mathrm{x}}$ conversion follows that of $\mathrm{CH}_{4}$ conversion and reaches a broad maximum where $\mathrm{CH}_{4}$ conversion is close to completion. This indicates that $\mathrm{CH}_{4}$ is used as a reducing agent during $\mathrm{SCR}$ of $\mathrm{NO}$.

It is evident from Figure 1[A]-curve (2) that in presence of water vapor, $\mathrm{NO}_{x}$ conversion is suppressed in the entire temperature range from 350 to $600{ }^{\circ} \mathrm{C}$. At $500^{\circ} \mathrm{C}$, the conversion falls from $85 \%$ to $68 \%$. Deleterious effect of water vapor on the activity of Ga-, In-, Co-exchanged zeolites for $\mathrm{NO}_{x}$ reduction with methane had been commonly observed whereas a better water tolerance had been achieved for Pd-ZSM-5 catalysts containing the second metal ions including $\mathrm{Rh}^{13}$ or $\mathrm{Co}^{14}$ Also, it is observed that in the presence of $\mathrm{SO}_{2}$, the $\mathrm{NO}_{3}$ conversion is drastically suppressed at lower temperatures. At $425^{\circ} \mathrm{C}$, the $\mathrm{NO}$ conversion falls from $70 \%$ to $40 \%$. However, at higher temperatures, the effect is not severe, and at $500^{\circ} \mathrm{C}$, the NOx conversion is almost same even in the presence of $\mathrm{SO}_{2} . \mathrm{Z} . \mathrm{Li}$ et $a I^{15}$ have reported that inhibition of the $\mathrm{SCR}$ reaction at low temperatures is caused by $\mathrm{SO}_{2}$ adsorption on the active sites over Ce-Ag-ZSM-5 catalyst. However, this is fully reversible with temperature. In the presence of both $\mathrm{H}_{2} \mathrm{O}$ and $\mathrm{SO}_{2}$, Figure 1[A]-curve-4, the catalytic activity of $\mathrm{Pd} / \mathrm{H}-$ ZSM-5 is reduced considerably at lower temperatures and remains active only at higher temperature. Figure 1[B] shows the activity of mixed catalsyt for the reduction of NOx with methane. This mixed catalyst is made by physically mixing the $1 \mathrm{wt} \% \mathrm{Pd} / \mathrm{HZSM}-5$ with $12.3 \mathrm{wt} \% \mathrm{CeO}_{2}-5$ $\mathrm{wt} \% \mathrm{MgO} / \mathrm{MgAl}_{2} \mathrm{O}_{4}(1: 1$ weight ratio). The mixed catalsyt showed a maximum activity $(91 \%)$ at $497^{\circ} \mathrm{C}$ in the absence of $\mathrm{SO}_{2}$ and $\mathrm{H}_{2} \mathrm{O}$. In the presence of water vapor, the $\mathrm{NOx}$ conversion is almost the same $(90 \%)$. However, the temperature window becomes narrower than the dry condition. In the presence of $\mathrm{SO}_{2}$, the $\mathrm{NO}_{x}$ conversion decreases to $87 \%$ 

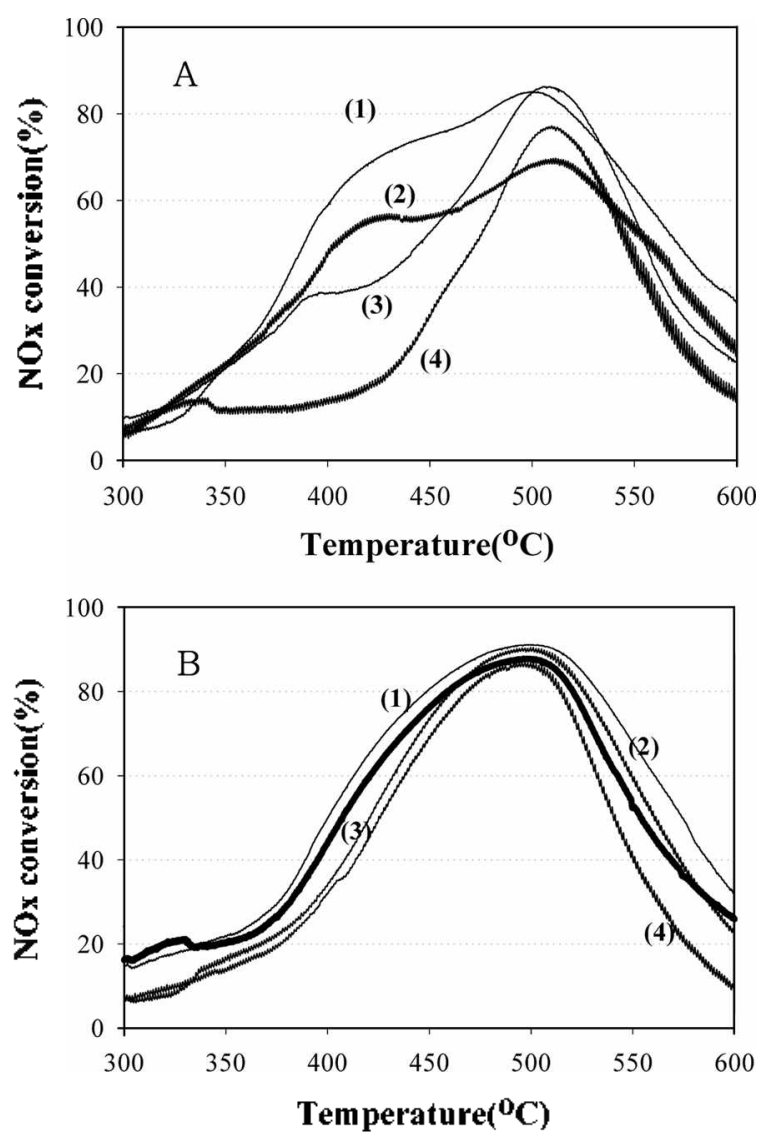

Figure 1. $N O_{x}$ conversion as a finction of temperature during SCR of $\mathrm{NO}$. [A] ] $\mathrm{wt} \% \mathrm{Pd} / \mathrm{H}-\mathrm{ZSM}-5,[\mathrm{~B}]$ inixed catalyst. (I) NO 1250 ppin, $\mathrm{CH}_{4} 4500$ ppin, $\mathrm{O}_{2} 3 \%$. (2) (1) $+\mathrm{H}_{2} \mathrm{O} 3 \%$. (3) (1) $+\mathrm{SO}_{2} 30$ ppm. (4) (1) $+\mathrm{H}_{2} \mathrm{O} 3 \%+\mathrm{SO}_{2} 30 \mathrm{ppm}$, and GHSV $=20,000 \mathrm{~h}^{-1}$. The mixed catalyst consists of $50 \mathrm{wt}^{\circ} \%$ of $1 \mathrm{wt} \% \mathrm{Pd} / \mathrm{HZSM}-5$ in the mixture of ' $\mathrm{wt} \% \mathrm{Pd} / \mathrm{HZSM}-5$ and $12.3 \mathrm{wt} \% \mathrm{CeO}_{2}-5 \mathrm{wt} \% \mathrm{MgO} /$ $\mathrm{MgNl}_{2} \mathrm{O}_{4}$.

than in the absence of $\mathrm{SO}_{2}$ at a wide temperature range. With $\mathrm{H}_{2} \mathrm{O}$ and $\mathrm{SO}_{2}$ there is again a little reduction of the catalytic activity $(86 \%)$ and temperature window becomes narrower. The mixed catalyst shows much higher activity, although it was obtained by physical mixing. The $12.3 \mathrm{wt} \% \mathrm{CeO}_{2} / 5$ wt $\% \mathrm{MgO} / \mathrm{MgAl}_{2} \mathrm{O}_{4}$ itself shows no activity in $\mathrm{NO}_{\mathrm{x}}$ reduction. The highest catalytic activity was observed when the mixed catalyst consist of $50 \mathrm{wt} \%$ of $\mathrm{I} \mathrm{wt} \% \mathrm{Pd} / \mathrm{HZSM}-5$ in the mixture of $\mathrm{I} \mathrm{wt} \% \mathrm{Pd} / \mathrm{HZSM}-5$ and $12.3 \mathrm{wt} \% \mathrm{CeO}_{2}-5$ $\mathrm{wt} \% \mathrm{MgO} / \mathrm{MgAl}_{2} \mathrm{O}_{4}$.

An interesting finding in this work is the observation of hyperfine structure of ESR spectrum which is indicated in Figure 2. When oxygen is contacted at $100-200^{\circ} \mathrm{C}$ onto $\mathrm{Pd} /$ H-ZSM-5 six hyperfine lines is observed due to the interaction between $\left.{ }^{27} \mathrm{~A}\right]$ nucleus $(\mathrm{I}=5 / 2)$ and the uripaired electron of superoxide ion, $\mathrm{O}_{2}{ }^{-}$. ESR parameters, $\mathrm{g}_{\|}=2.043$, $\mathrm{A}_{\|}=6 \mathrm{G}$ and $\mathrm{g}_{\perp}=2.017$, is similar to the previous report. ${ }^{7}$ This result indicates that there are some Lewis acid sites on $\mathrm{Pd} / \mathrm{H}-\mathrm{ZSM}-5$ zeolite and aluminum atom is involved in the adsorption site for the $\mathrm{O}_{2}^{-}$ion. And also $\mathrm{O}_{2}{ }^{-}$species formed

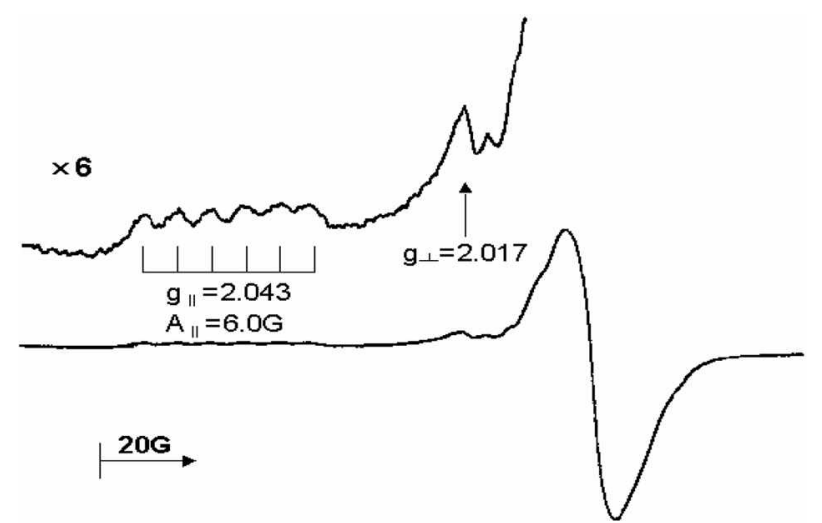

Figure 2. ESR spectra at $77 \mathrm{~K}$ of $\mathrm{O}_{2}$ adsorbed on $1 \mathrm{wt} \% \mathrm{Pd} / \mathrm{H}-$ ZSM-5.

may be adsorbed aluminum site by which methane can be activated to enhance the NO-SCR activity.

Overall, the addition of modified layered oxide to $\mathrm{Pd} / \mathrm{H}$ ZSM-5 catalyst can increase the selective catalytic reduction of $\mathrm{NO}_{\mathrm{x}}$ with methane in the presence of excess $\mathrm{O}_{2} \mathrm{H}_{2} \mathrm{O}$ and $\mathrm{SO}$. Not only highly dispersed $\mathrm{PdO}$ and $\mathrm{Pd}^{2+}$ or the Bronsted acid site but also Lewis acid site in $\mathrm{Pd} / \mathrm{H}-\mathrm{ZSM}-5$ are responsible active sites for SCR of NO. And it seems that modified layered oxide $\left(\mathrm{CeO}_{2}-\mathrm{MgO} / \mathrm{MgAl}_{3} \mathrm{O}_{4}\right)$ can retard the thermal decomposition of $\mathrm{Pd}$-species and enhance durability against $\mathrm{SO}_{2}$ poisoning in the presence of excess $\mathrm{O}_{2}$ and $\mathrm{H}_{2} \mathrm{O}$.

Acknowledgement. This work was supported by KOGAS and the grant No. R01-2003-000-10069-0 from the Basic Research Program of the Korea Science \& Engineering Foundation.

\section{References}

I. Li, Y.; Armor, J. N. US. Paten 1992, 5, 149,512.

2. Kaucky, D.; Vondrova, A.; Dedecek, J.; Witcherlova, B. J. Catal. $2000,794,318$.

3. Campa, M. C.; Pietrogiacomi, D.; Tuti, S.; Ferraris, G.; Indovina, V. Appl. Catal, B 1988, $18,15 \mathrm{I}$.

4. Li, Y.; Armor, J. N. J. Catal. 1994, 145, I.

5. Yogo, K.; Kikuchi, E. Stud. Strf. Sci. Catal. 1994, 84, 1547.

6. Wang, X.; Zhang, T.; Xu, C.; Sun, X.; Liang, D.; Lin, L. Chem. Commin. 2000, 279 .

7. Nishizaka, Y.; Misono, M. Chem. Lett, 1994, 237.

8. Wen, B.; Sun, Q.; Sachtler, W. M. H. J. Catal. 2001, 204, 314.

9. Li, Z.F Flytzani-Stephanopoulos, M. Appl. Catal. A 1997, $165,15$.

10. Li, Y.; Armor, J. N. Appl. Catal. B 1993, 3, L1.

11. Li, Y.; Armor, J. N. Appl. Catal. B 1995, 5, L257.

12. Park, Y. K.; Lee, J. W.; Lee, C. W.; Park, S. E. J. Mol. Catal. A $2000,158,173$.

13. Misono, M.; Nishizaka, Y.; Kawamolo, M.; Kato, K. Stud. Sulf. Sci. Catal. 1997, 105, 1501.

14. Ogura, M.; Sugiura, Y.; Hayashi, M.; Kikuchi, E. Catal. Lett. 1996, $42,185$.

15. Li, Z.; Flytzani-Stephanopoulos, M. Appl. Catal. B 1999, 22, 35.

16. Vaccari, A, Appl. Clay Sci, 1999, 14, 161.

17. Wang, K. M.; Lunsford, J. H. J. Ph:s. Chem. 1969, 73, 2069. 